\title{
Uji Aktivitas Antibakteri dari Ekstrak n-Heksana dan Kloroform Daun Sirsak (Annona muricate L.) Terhadap Pertumbuhan Bakteri Staphylococcus aureus Secara In Vitro
}

\author{
(ANTIBACTERIAL ACTIVITY OF EXTRACT n-HEKSANA AND CHLOROFORM OF \\ SOURSOP LEAF (Annona muricata L.) ON GROWTH OF BACTERIAL Staphylococcus \\ aureus In Vitro)
}

\author{
Werenfridus Kono Lake ${ }^{1 *}$, Iwan Sahrial Hamid², Amung Logam Saputro ${ }^{3}$, Hani \\ Plumeriastuti $^{4}$, Lita Rakhma Yustinasari ${ }^{5}$, Maya Nurwartanti Yunita ${ }^{4}$ \\ ${ }^{1}$ Bachelor of Veterinary Medicine, \\ ${ }^{2}$ Department of Basic Veterinary Science, \\ ${ }^{3}$ Department of Veterinary Clinic and Animal Hospital, \\ ${ }^{4}$ Department of Veterinary Pathology, \\ ${ }^{5}$ Department of Veterinary Anatomy, \\ Faculty of Veterinary Medicine, Universitas Airlangga, \\ UNAIR C-Campus Mulyorejo, Surabaya, Jawa Timur, Indonesia, 60115 \\ Telp. (031)5993016, Fax. (031)5993015 \\ *Corresponding author: werenfridus.k.lake-2014@ @kh.unair.ac.id
}

\begin{abstract}
Abstrak
Penelitian ini bertujuan untuk mengetahui aktivitas antibakteri daun sirsak terhadap Staphylococcus aureus. Ekstraksi diproses dengan metode maserasi terlebih dahulu dengan n-heksana kemudian kloroform. Aktivitas antibakteri diukur secara in vitro dengan menggunakan metode difusi agar menggunakan paperdisk. Aktivitas antibakteri diuji dengan analisis variansi (ANOVA) dengan nilai signifikansi 0,5\% untuk mengetahui pengobatan mana yang memiliki efek atau berbeda secara signifikan dengan dosis masing-masing $300 \mathrm{mg} / \mathrm{ml}$, $250 \mathrm{mg} / \mathrm{ml}, 200 \mathrm{mg} / \mathrm{ml}, 150 \mathrm{mg} / \mathrm{ml}, 100 \mathrm{mg} / \mathrm{ml}$ dan menghasilkan aktivitas antibakteri dengan zona hambat berturut-turut $16,70 \mathrm{~mm} ; 14,05 \mathrm{~mm} ; 11,45 \mathrm{~mm} ; 9,85 \mathrm{~mm} ; 3,00$. Hasil pemeriksaan aktivitas antibakteri menunjukkan ekstrak n-heksana dan kloroform dapat menghambat pertumbuhan Staphylococcus aureus pada konsentrasi $250 \mathrm{mg} / \mathrm{ml}$ dengan diameter zona hambat 14,05 mm. Ekstrak dengan aktivitas tertinggi ditentukan konsentrasi hambat tumbuh minimum (MIC). Ekstrak kloroform daun sirsak dari bakteri Staphylococcus aureus yang berada pada konsentrasi $100 \mathrm{mg} / \mathrm{ml}$ dengan zona hambat 3,00 mm.
\end{abstract}

Kata kunci: Annona muricata L, antibakteri, ekstrak kloroform, Staphylococcus aureus

\begin{abstract}
This study aimed to determine the antibacterial activity of soursop leaf against Staphylococcus aureus. The extraction was processed by maceration method first with $n$-hexane then chloroform. The antibacterial activities were measured in vitro by means of agar diffusion method using paperdisk. The antibacterial activity was tested by analysis of variance (ANOVA) with a significance value of $0.5 \%$ to know which treatment had an effect or significantly different with a dose respectively $300 \mathrm{mg} / \mathrm{ml}, 250 \mathrm{mg} / \mathrm{ml}, 200 \mathrm{mg} / \mathrm{ml}, 150 \mathrm{mg} / \mathrm{ml}, 100$ $\mathrm{mg} / \mathrm{ml}$ and produce antibacterial activity with consecutive inhibition zone of 16,70 mm; 14,05 mm; 11,45 mm; $9,85 \mathrm{~mm} ; 3,00$. The results of antibacterial activities examination showed chloroform extract can inhibited the growth of Staphylococcus aureus at concentration $250 \mathrm{mg} / \mathrm{ml}$ with inhibitation zone diameter were $14.05 \mathrm{~mm}$. Extract with the highest activity determined the minimum inhibitory concentrations grow (MIC). MIC soursop leaf chloroform extract of the Staphylococcus aureus bacteria that was at a concentration of $100 \mathrm{mg} / \mathrm{ml}$ with inhibition zone of $3.00 \mathrm{~mm}$.
\end{abstract}

Key words: Annona muricata L, antibacterial, chloroform extract, Staphylococcus aureus 


\section{PENDAHULUAN}

Tanaman sirsak (Annona muricata L.). sering digunakan di Indonesia dikenal masyarakat untuk pengobatan luar, khususnya penyakit kulit. Tahun 2010 buah dari tanaman sirsak diketahui berkhasiat untuk mengobati disentri, empedu akut, kencing batu dan penyakit kulit. Daun sirsak berfaedah untuk mengatasi luka borok, bisul, kejang, kutu rambut dan jerawat (Ningsih dkk., 2017). Daun sirsak mampu mengatasi jerawat akibat infeksi bakteri yang sering ditemukan pada jerawat. Bakteri gram positif penyebab utama jerawat yaitu Staphylococcus aureus dan Propionibacterium acnes (Melisa dkk., 2015).

Staphylococcus aureus terdapat pada saluran pernafasan atas, saluran kencing, mulut dan hidung, jaringan kulit bagian dalam dari bisul bernanah, infeksi luka, radang paru-paru dan selaput lendir lainnya. Antibiotik eritromisin sering digunakan dalam membunuh Staphylococcus aureus. Penggunaan antibiotik sering menyebabkan resistensi bakteri terhadap zat antibiotik. Resistensi Staphylococcus aureus terhadap antibiotik yang sering digunakan sudah mencapai angka persentase yang tinggi (30-70\%) (Melisa dkk., 2015).

Penggunaan obat tradisional dijadikan sebagai alternatif pengobatan, dalam mengatasi masalah kesehatan, pencegahan, dan penyembuhan suatu penyakit (Hariana, 2006). Salah satu tanaman yang digunakan dalam pengobatan tradisional pengganti antibiotik resisten ialah ekstrak daun sirsak. Ekstrak methanol daun sirsak memiliki kandungan utama sebagai antibakteri yaitu saponin, tanin, alkaloid, dan flavonoid (Wijaya, 2012).

Ekstrak methanol daun sirsak dengan metode maserasi memiliki aktivitas antibakteri karena dapat menghambat pertumbuhan bakteri Staphylococcus aureus pada konsentrasi 150 $\mathrm{mg} / \mathrm{ml}$ dengan diameter daerah hambat sebesar 14,1 mm yang di kategorikan sebagai antibakteri dan konsentrasi $5 \mathrm{mg} / \mathrm{ml}$ dengan diameter hambat sebesar $8 \mathrm{~mm}$ yang di kategorikan sebagai Konsentrasi Hambat Tumbuh Minimum (KHTM) (Utami, 2013). Hasil uji ekstrak kloroform daun sirsak menyebabkan zona hambatan E. coli 8,34 mm, melebihi ekstrak dengan n-heksana dan ekstrak methanol (Ningsih dkk., 2016).

Berdasarkan latar belakang diatas perlu dilakukan penelitian mengenai uji aktivitas antibakteri dari ekstrak n-heksana dan kloroform daun sirsak (Annona muricata L.) melalui tingkat hambatan (mm) pada Staphylococcus aureus.

\section{METODE PENELITIAN}

Penelitian ini berlangsung pada bulan Januari-Maret 2018. Pembuatan ekstraksi dan perlakuan dilakukan di Laboratorium Instrumen Prodi Kedokteran Hewan PSDKU Universitas Airlangga di Banyuwangi. Penelitian ini menggunakan 11 perlakuan dengan bakteri pengujian ekstrak daun sirsak adalah Staphylococcus aureus (ATCC No. 25923) dilakukan di Laboratorium Instrumen Prodi Kedokteran Hewan PSDKU Universitas Airlangga di Banyuwangi.

Data aktivitas antibakteri yang diukur zona hambatnya dianalisis ragam ANAVA (Analisis Varian) satu arah untuk menguji adanya pengaruh atau perbedaan antara perlakuan variasi konsentrasi ekstrak daun sirsak (Annona muricata L.) pada pertumbuhan bakteri tingkat signifikansi 5\% untuk mengetahui perlakuan yang berpengaruh atau berbeda nyata diantara perlakuan yang lain.

Alat dan bahan yang digunakan dalam penelitian ini Rotary evaporator Merk IKA RV 10 digital / IKA HB 10, Vacuum Pump Merk GAST Model Doa-P604-PN. Kulkas merk Politron, timbangan digital merk OHAUS PA 214, timbangan Type Scale Merk Lion Star, Blender CB 721 G Cosmos, Inkubator merk BINDER BD.53, Autoclave merk ALL AMERICAN 25x, baker glass, Shaker inkubator (Memert Jerman), filler, pipet ukur, gelas ukur, erlenmeyer, corong Buchner dan pompa vakum, hot plate stirrer, pipet mikro otomatis, pipet volume, pembakar bundsen, jarum ose, jangka sorong, spatula, masker, glove, tabung reaksi, daun sirsak, kloroform, n-heksana, isolat bakteri Staphylococcus aureus (ATCC No. 25923), 
Muller Hinton Agar (MHA), eritromisin, aquades steril, alkohol 70\%, (Carboxymethyl Cellulose) CMC-Na 0,5\%, MSA, kertas saring, tisu, $\mathrm{NaCl}$ steril 0,9\%, wrapping, kapas, kain kassa, aluminium foil, Standar Mcfarlan 0,5.

Prosedur penelitian menggunakan 800 gr serbuk daun sirsak 3 liter n-heksana dan kloroform didiamkan tanpa sinar matahari dan diaduk 4 jam sekali selama 3 hari, kemudian selama seminggu prosedur maserasi dengan larutan kloroform 3 liter dilakukan. Metode penelitian menggunakan sembilan perlakuan konsentrasi ekstrak n-heksana dan klorofrorm. Ekstrak daun sirsak ditimbang sebanyak $3 \mathrm{~g}$ dan dilarutkan dengan CMC 1\% (Carboxymethyl Cellulose) hingga $10 \mathrm{ml}$ maka konsentrasi ekstrak adalah $300 \mathrm{mg} / \mathrm{ml}$ selanjut nya diencerkan menjadi sembilan dosis secara bertingkat menggunakan pelarut n-heksana dan kloroform. (Utami, 2013).

Pembuatan supensi Staphylococcus aureus untuk dilakukan uji sensitivitas dengan indikator kekeruhan yang disamakan dengan standar Mc Farlands $0,5 \%$ yang mengandung $3 \times 108$ bakteri (Ferianto, 2012). Persiapan tiga cawan petri yang diberi $20 \mathrm{ml}$ Muller hinton agar steril yang telah dihomogenkan dan dibiarkan media memadat. Pemberian 0,1 ml larutan Staphylococcus aureus sesuai standar Mc Farlans 0,5 dari Staphylococcus aureus dituangkan ke permukaan media muller hinton agar, kemudian kertas disk (diameter $6 \mathrm{~mm}$ ) yang direndam ke dalam larutan uji dengan berbagai konsentrasi, dikeringkan dan diletakkan di atas permukaan media agar (Ningsih dkk., 2017).

Satu cawan petri dibagi dalam empat daerah berisi masing-masing satu kertas cakram kemudian diinkubasi pada suhu $36-37^{\circ} \mathrm{C}$ selama 18-24 jam. Diameter daerah hambat disekitar kertas disk diukur dengan jangka sorong empat kali pengukuran diameter daerah hambat terhadap Staphylococcus aureus (Utami, 2013).

\section{HASIL DAN PEMBAHASAN}

Penelitian ini dilakukan secara in vitro menggunakan eksrak daun sirsak (Annona muricata L.). Konsentrasi perlakuan yang digunakan merupakan konsentrasi bertingkat dan dibagi menjadi sembilan kelompok konsentrasi ekstrak dan dua kelompok kontrol perlakuan yaitu kelompok kontrol negatif (K-) dan kelompok kontrol positif $(\mathrm{K}+)$.

Kelompok kontrol negatif (K-) diberikan CMC-Na sedangkan kelompok kontrol positif $(\mathrm{K}+)$ menggunakan eritromisin. Kelompok perlakuan satu (P1) $300 \mathrm{mg} / \mathrm{ml}$ ekstrak daun sirsak, kelompok perlakuan dua (P2) $250 \mathrm{mg} / \mathrm{ml}$ ekstrak daun sirsak, kelompok perlakuan tiga (P3) $200 \mathrm{mg} / \mathrm{ml}$ ekstrak daun sirsak, kelompok perlakuan empat (P4) $150 \mathrm{mg} / \mathrm{ml}$ ekstrak daun sirsak, kelompok perlakuan lima (P5) $100 \mathrm{mg} / \mathrm{ml}$ ekstrak daun sirsak, kelompok perlakuan enam (P6) $50 \mathrm{mg} / \mathrm{ml}$ ekstrak daun sirsak, kelompok perlakuan tujuh (P7) $25 \mathrm{mg} / \mathrm{ml}$ ekstrak daun sirsak, kelompok perlakuan delapan (P8) 10 $\mathrm{mg} / \mathrm{ml}$ ekstrak daun sirsak dan kelompok perlakuan sembilan (P9) $5 \mathrm{mg} / \mathrm{ml}$ ekstrak daun sirsak.

Berdasarkan Tabel 1. Hasil menunjukkan bahwa rerata diameter daerah hambat pada $\mathrm{K}+$ $22,10^{\mathrm{f}}$ memiliki diameter daerah hambat terbesar sedangkan pada K- 0,00 tidak terdapat daerah hambat. Nilai rerata ini menunjukkan bahwa ada perbedaan yang nyata antara $\mathrm{K}$ - dengan $\mathrm{K}+$. Nilai rerata diameter daerah hambat pada $\mathrm{P} 1$ yaitu $16,70^{\mathrm{e}}$, lebih kecil dari pada $\mathrm{K}+$. Nilai rerata ini menunjukkan bahwa ada perbedaan yang nyata antara $\mathrm{K}+$ dengan $\mathrm{P} 1$. P2 memiliki nilai rerata diameter daerah hambat sebesar $14,45^{\text {d}}$. Nilai rerata ini menunjukkan ada perbedaan yang nyata antara $\mathrm{K}-, \mathrm{K}+$ dan P1. P3 yang memiliki nilai rerata $11,45^{\mathrm{c}}$ dan $\mathrm{P} 4$ yang memiliki nilai rerata $9,85^{\mathrm{c}}$ menunjukkan tidak ada nya perbedaan yang nyata, sedangkan P5 yang memilki nilai rerata $3,00^{\mathrm{b}}$ menunjukan perbedaan yang nyata antara $\mathrm{K}-, \mathrm{K}+, \mathrm{P} 1, \mathrm{P} 2, \mathrm{P} 3$ dan P4.

Hasil perlakuan dilihat setelah 24 jam proses inkubasi melalui pengukuran diameter daerah hambat. Diameter daerah hambat yang di ukur sebanyak empat kali menggunakan jangka sorong. Pengamatan dilakukan pada daerah bening yang terbentuk di sekitar disk. 
Tabel 1. Rerata diameter daerah hambat ekstrak Annona muricata L terhadap Staphylococcus aureus

\begin{tabular}{cc}
\hline Perlakuan & Mean \pm SD \\
\hline K- & $0,00^{\mathrm{a}} \pm 0,00$ \\
K+ & $22,10^{\mathrm{f}} \pm 0,42$ \\
P1 & $16,70^{\mathrm{e}} \pm 0,71$ \\
P2 & $14,05^{\mathrm{d}} \pm 1,20$ \\
P3 & $11,45^{\mathrm{c}} \pm 0,78$ \\
P4 & $9,85^{\mathrm{c}} \pm 0,35$ \\
P5 & $3,00^{\mathrm{b}} \pm 0,00$ \\
P6 & $0,00^{\mathrm{a}} \pm 0,00$ \\
P7 & $0,00^{\mathrm{a}} \pm 0,00$ \\
P8 & $0,00^{\mathrm{a}} \pm 0,00$ \\
P9 & $0,00^{\mathrm{a}} \pm 0,00$ \\
\hline
\end{tabular}

Keterangan: Superskrip yang berbeda pada kolom yang sama menunjukkan adanya perbedaan yang nyata antar perlakuan $(\mathrm{p}<0,05)$

Hasil penelitian telah diperoleh dan membuktikan terdapat diameter daerah hambat pada beberapa perlakuan. Penentuan konsentrasi hambat tumbuh minimum (KHTM) bertujuan untuk menentukan konsentrasi minimum pada ekstrak n-heksana dan kloroform daun sirsak dalam menghambat pertumbuhan bakteri uji. Zona bening disekitar zat antimikroba merupakan kekuatan hambatan zat antimikroba terhadap penghambatan pertumbuhan mikroorganisme, ditunjukkan dengan adanya diameter zona hambat atau daerah transparan disekitar disk pada pertumbuhan bakteri. Zona hambat yang dihasilkan hanya bersifat menghambat pertumbuhan bakteri (bakteriostatik) dan tidak bersifat membunuh bakteri (bakteriosidal). Hal ini ditunjukkan dengan mengecilnya ukuran zona hambat setelah fasa logaritmik dari bakteri. (Marselia dkk., 2015).

Hasil uji statistik One Way ANOVA menunjukan terdapat perbedaan yang nyata pada setiap konsentrasi ekstrak n-heksana dan kloroform daun sirsak dalam menghambat pertumbuhan Staphylococcus aureus. Perbedaan konsentrasi ekstrak n-heksana dan kloroform daun sirsak yang diberikan pada setiap perlakuan menunjukkan perbedaan signifikan pada zona hambat yang dihasilkan, dimana pemberian konsentrasi ekstrak tertinggi $300 \mathrm{mg} / \mathrm{ml}$ dan terendah $100 \mathrm{mg} / \mathrm{ml}$ yang menghasilkan zona hambat berturut sebesar $16,70 \mathrm{~mm}$ dan $3,00 \mathrm{~mm}$. Konsentrasi $100 \mathrm{mg} / \mathrm{ml}$, memberikan diameter sebesar 3,00 $\mathrm{mm}$ di kategorikan sebagai
Konsentrasi Hambat Tumbuh Minimum (KHTM) setelah diukur dan dianalisis. Penentuan KHTM dari suatu senyawa antibakteri sangat penting karena selain bertujuan untuk meningkatkan efektivitas dari senyawa antibakteri tersebut juga bertujuan untuk mencegah timbulnya masalah resistensi bakteri karena penggunaan dosis yang berlebihan sehingga sel bakteri lama kelamaan akan menjadi kebal (Diarti, 2014).

Kenaikan konsentrasi ekstrak n-heksana dan kloroform daun sirsak akan meningkatkan aktivitas antibakterinya, disebabkan semakin banyak zat aktif yang terkandung dalam ekstrak dan menunjukkaan zona hambat pertumbuhan Staphylococcus aureus setelah pemberian ekstrak n-heksana dan kloroform daun sirsak (Annona muricata L.) yang dihubungkan dengan senyawa yang terkandung pada ekstrak kloroform daun sirsak (Annona muricata L.) yaitu meliputi alkaloid, flavonoid, dan steroid/triterpenoid. Diameter daerah hambat pertumbuhan bakteri yang terbentuk dari ekstrak n-heksana dan kloroform daun sirsak sebesar $16,70 \mathrm{~mm}$ pada konsentrasi $300 \mathrm{mg} / \mathrm{ml}$ dan $14,01 \mathrm{~mm}$ pada konsentrasi $250 \mathrm{mg} / \mathrm{ml}$ tampak lebih luas dibandingkan dengan fraksi kloroform daun sirsak. Fraksi kloroform daun sirsak hanya dapat menghambat pertumbuhan bakteri Staphylococcus aureus pada konsentrasi 300 $\mathrm{mg} / \mathrm{ml}$ dengan diameter daerah hambat sebesar $12,10 \mathrm{~mm}$ dan pada konsentrasi $250 \mathrm{mg} / \mathrm{ml}$ dengan diameter daerah hambat sebesar 11,50 mm (Utami, 2013). 
Fraksi kloroform terlebih dahulu di ekstraksi dengan pelarut methanol yang bersifat polar sehingga sebagian zat antibakteri yang larut pada pelarut semi polar tidak larut pada methanol, sedangkan ekstrak bertingkat dengan n-heksana dan kloroform dapat melarutkan zat lebih tinggi dibandingkan dengan fraksi kloroform sehingga zat aktif yang terkandung dalam ekstrak nheksana dan kloroform lebih banyak dikarenakan pelarut $n$-heksana bersifat non polar sedangkan kloroform bersifat semi polar nampak pada hasil penelitian ekstrak kloroform S. vulgare yang menunjukkan aktivitas antibakteri sedangkan ekstrak etanol dan n-heksana sebaliknya, membuktikan senyawa aktif antibakteri falvonoid dan steroid cenderung terdistribusi pada pelarut semipolar (Alfiyaturohmah dkk., 2013).

Sjahid (2008) menyebutkan konsentrasi ekstrak dewandaru (Eugenia uniflora L.) mengandung senyawa flavonoid, alkaloid dan steroid yang dapat menyebabkan rusaknya susunan dan perubahan mekanisme permeabilitas dinding sel bakteri. Mekanisme senyawa alkaloid yaitu komponen alkaloid diketahui sebagai interkelator DNA dan menghambat enzim topoisomerase sel bakteri. Mekanisme steroid sebagai antibakteri menyebabkan kebocoran pada liposom karena berinteraksi dengan membran fosfolipid sel yang menyebabkan integritas membran menurun serta morfologi membran sel berubah yang menyebabkan sel rapuh dan lisis. Bakteri gram positif yaitu Staphylococcus aureus lebih rentan dibandingkan bakteri gram negatif yaitu E.coli terhadap senyawa kimia yang disebabkan oleh perbedaan komposisi dan struktur dinding sel pada bakteri gram positif dan gram negatif (Utami, 2013).

Efektivitas ektrak n-heksan dan kloroform daun sirsak terhadap Staphylococcus aureus yang tergolong bakteri gram positif tampak pada zona hambat yang terbentuk pada setiap perlakuan yang peka terhadap paparan senyawa antibakteri. Sel bakteri gram positif memiliki selubung sel yang terdiri atas membran sel dan lapisan peptidoglikan yang tebal (dinding sel) dan berlapis tunggal (mono) dengan kandungan lipid yang rendah (1-4\%) sedangkan bakteri gram negatif berlapis tiga (multi) yang terdiri dari lapisan luar lipoprotein, lapisan tengah lipopolisakarida, dan lapisan dalam berupa peptidoglikan dengan kandungan lipid yang tinggi yaitu 11-12\% (Jawetz, 2001).

\section{KESIMPULAN}

Aktivitas antibakteri secara in vitro diperoleh hasil bahwa ekstrak bertingkat dengan pelarut n-heksana dan kloroform mampu menghambat bakteri Staphylococcus aureus pada konsentrasi $250 \mathrm{mg} / \mathrm{ml}$ dengan diameter daerah hambat sebesar $14,05 \mathrm{~mm}$ dan nilai KHTM pada konsentrasi $100 \mathrm{mg} / \mathrm{ml}$, memberikan diameter daerah hambatan sebesar $3,00 \mathrm{~mm}$.

\section{UCAPAN TERIMA KASIH}

Terima kasih kepada Laboratorium instrumental PSDKU Universitas Airlangga Banyuwangi sebagai pemberi fasilitas penelitian ini.

\section{DAFTAR PUSTAKA}

Alfiyaturohmah, Rachmawati, N., Eriyanto, Y. 2013. Uji Aktivitas Antibakteri Ekstrak Kasar Etanol, Kloroform Dan N-Heksana Alga Coklat Sargassum Vulgare Asal Pantai Kapong Pamekasan Terhadap Bakteri Staphilococcus aureus Dan Eschericia coli. 101-149.

Diarti, M. W. 2004. Penemu senyawa antimikroba dari rumput laut. Harian Umum Kompas. 1-3.

Ferianto, A. 2012. Pola Resistensi Staphylococcus aureus yang Diisolasi dari Mastitis pada Sapi Perah di Wilayah Kerja KUD Argopuro Krucil Probolinggo Terhadap Antibiotika [Skripsi]. Departemen Kedokteran Dasar. Fakultas Kedokteran Hewan. Universitas Airlangga. 
Jawetz, E. 2001. Mikrobiologi Kedokteran. Surabaya/ Penerbit Salemba Medika.

Marselia, S., Agus, M. W., Arrenuz, S. 2015. Aktivitas Antibakteri Ekstrak Daun Soma (Ploiarium alternifolium melch) Terhadap Propionibacterium acnes. Program Studi Kimia, Fakultas MIPA, Universitas Tanjungpura, 74-80.

Melisa, R. T., Billy, J., Kepel, Michael, A.L. 2015. Uji daya hambat ekstrak daun sirsak (Annona muricata L.) terhadap pertumbuhan Staphylococcus aureus secara in vitro. 23022493.

Ningsih, D. R., Zusfahair, Kartika, D. 2016. Identifikasi Senyawa Metabolit Sekunder Serta Uji Aktivitas Ekstrak Daun Sirsak sebagai Antibakteri. Purwokerto. Molekul. 101-111.
Ningsih D. R., Zusfahair, Kartika, D. 2017 Aktivitas ekstrak kloroform daun sirsak (Annona muricata L.) sebagai antibakteri terhadap Propionibacterium acnes. Jurnal Penelitian Saintek, 1(4), 22

Sjahid, L. R. 2008. Isolasi dan Identifikasi Flavonoid dari Daun Dewandaru (Eugenia uniflora L.). [Skripsi]. Universitas Muhammadiyah Surakarta.

Utami, N. P. 2013. Skripsi Skrining Fitokimia dan Uji Aktivitas Antibakteri Dari Ekstrak Metanol dan Fraksikloroform Daun Sirsak (Annona Muricata L.) [Skripsi]. Fakultas Farmasi Universitas Sumatera Utara.

Wijaya, M. 2012. Ekstraksi Annonaceous Acetogenin dari Daun Sirsak, Annona Muricata, sebagai Senyawa Bioaktif Antikanker [Skripsi]. Fakultas Kedokteran Universitas Indonesia. 